\title{
Hagar and Epistemic Injustice: An Intercultural and Post-colonial Analysis of Genesis 16
}

\author{
Beth E. Elness-Hanson (Johannelund School of Theology, \\ UPPSALA, SWEDEN / VID SPECIALIZED UNIVERSITY, STAVANGER, \\ NORWAY)
}

\begin{abstract}
Having one's voice heard and being known by one's name are foundational aspects of respect and human dignity. Likewise, being able to contribute to shared understanding is at the core of epistemic justice. This intercultural and post-colonial inquiry of Gen 16 considers the Egyptian Hagar - known by her foreign Semitic name meaning "Fleeing One"-as an example of epistemic injustice. Integrating Miranda Fricker's work on epistemic injustice, this study espouses the justice of hearing and seeing the marginalised and oppressed, as exemplified by YHWH. As the Egyptian woman's voiceonce ignored-gives testimony within the text to a fuller understanding of God, so also listening to/seeing other contemporary African scholars' voices/writings opens one's ears/eyes to fuller understandings of God today. These voices include the seminal work of David Tuesday Adamo, a vanguard in African biblical hermeneutics, in whose honour this examination is written.
\end{abstract}

KEYWORDS: Genesis 16, Hagar, epistemic injustice, Miranda Fricker, David Tuesday Adamo, African biblical hermeneutics, intercultural and post-colonial criticism

\section{A INTRODUCTION}

In leading up to the 2020 election in the USA, Fox News host Tucker Carlson was mispronouncing the name of the Democratic vice-presidential running mate, Kamala Harris. ${ }^{1}$ When Richard Goodstein politely corrected the pronunciation, Carlson responded, "Okay, so what?" Goodstein cautioned that correctly

* Submitted: 28/04/2021; peer-reviewed: 23/06/2021; accepted: 07/08/2021. Beth E. Elness-Hanson, "Hagar and Epistemic Injustice: An Intercultural and Post-colonial Analysis of Genesis 16," 34 no. 2 (2021): 445 - 459. DOI: https://doi.org/10.17159/2312-3621/2021/v34n2a8.

1 Margaret Sullivan, "Perspective | Tucker Carlson's Mangling of Kamala Harris' Name Was All about Disrespect," Washington Post, n.p., https://www.washingtonpost.com/lifestyle/media/tucker-carlsons-mangling-ofkamala-harriss-name-was-all-about-disrespect/2020/08/12/ea573d06-dca7-11ea-809eb8be57ba616e story.html. Kamala is pronounced like the punctuation mark, comma, plus -la, or 'commala.' 
pronouncing a name is a bare minimum of respect. Carlson's pushback was seen as tone-deaf at best, especially when discussing a woman of colour. ${ }^{2}$

Those who hold respect ${ }^{3}$ as a core value are discouraged at how civility in political discourse is eroding away. Even more so, concerns continue over injustices levied against marginalised people and groups. Thus, this inquirywhile engaging an ancient text-speaks to myself and other readers today, examining how an interpretation of Gen 16 for our contemporary contexts canat a minimum - contribute to a call for respect and civil discourse in our postcolonial and increasingly multicultural world. On a deeper level, this analysis sensitises readers to the work of Miranda Fricker on "epistemic injustice." A core concern is working for justice for others to be able to contribute their knowledge to the pool of understanding in the speaker's world in order to enrich humankind. ${ }^{4}$ The narrative of Hagar in Gen 16 is an example of epistemic injustice-among other injustices - where her voice was unheard by the powerbrokers in the midst of an oppressive conflict, and furthermore, she is memorialised with a belittling Semitic name, as argued below.

This marginalisation from contributing to understanding and the pool of knowledge is not just Hagar's story, but in the continued emergence out of colonial contexts into ever-increasing multicultural contexts, those with other ways of knowing have been predominantly left out of contributing to the pool of knowledge. Yet when the voices of the marginalised are heard, the understandings are fuller, which is exemplified in Hagar's story, as described below and advocated for by strains of feminist epistemology, which is integrated below. The courageous voices that challenged the status quo and interrupted the dominant narratives include David Tuesday Adamo who raised the

2 Joe Grimm, "Associated Press Changes Style on Race, Gender," Bias Busters: Cultural Competence

Guides, n.p., https://news.jrn.msu.edu/culturalcompetence/2019/04/05/associated-press-changesstyl-on-race. "Woman of colour" like "person of colour" is the standard way to refer respectfully to people who are not from traditional European descent within the USA. It has limited but growing use in other English-speaking contexts.

3 "Meaning of Respect in English," Cambridge Dictionary, n.p., https://dictionary.cambridge.org/dictionary/english/respect. The understanding here is "politeness, honour, and care shown towards someone or something that is considered important."

4 Miranda Fricker, Epistemic Injustice: Power and the Ethics of Knowing (Oxford: Oxford University Press, 2009), 1, 110; Miranda Fricker, "Epistemic Equality?" (Lecture, Social Equality Conference, UCT Philosophy, Cape Town, South Africa, September 10, 2014), sec. 9:20, n.p., https://www.youtube.com/watch?v=u8zoN6GghXk. The aim of epistemic justice is to contribute "to the stock of shared meanings, to the pool of concepts and interpretive tropes that are at work at large in society." 
consciousness of Africa in the Bible and African scholars in international dialogues on biblical exegesis. In his honour, this analysis calls for epistemic justice.

\section{B SOCIAL LOCATION, DELIMITATIONS AND DEFINITIONS}

In intercultural hermeneutics, it is important to identify the social location to help clarify the situated knowledge represented. Thus, I am from the USA and currently living in Sweden. My worldview, as a young child, was shaped as the last-born female of missionaries serving in multi-lingual and multi-cultural Lutheran church in Hong Kong. Loving people who were culturally and ethnically different was normal. Inherent respect was modelled by my family in this cosmopolitan city where I was a moderately privileged ethnic and religious minority. As an adult, my three years as a volunteer teacher at a Lutheran high school for girls from the Maasai people group in Tanzania simulated continued research on intercultural biblical hermeneutics in Africa. ${ }^{5}$

Due to space limitations, this examination focuses on Hagar in Gen 16 and only has a cursory engagement with the continued Hagar account in Gen 21. This delimitation also means that the significant role that Hagar has in the Muslim tradition - a comparison to Gen 21 - is not developed here beyond a brief connection to the name of Hagar below.

Two definitions follow to clarify their use here. The first is epistemology. Simplified, epistemology asks, "How do we know what we know?" Matthias Steup explains, "Defined narrowly, epistemology is the study of knowledge and justified belief." In addition, epistemology can be used generally to refer to a "way of knowing." The adjectival form, epistemic, is synonymous with cognitive.

The second term is hermeneutics. While hermeneutics often focuses on methods of interpretation, I align with Charles Wood's definition that "Hermeneutics is critical reflection upon the practice of interpretation-its aims, conditions, and criteria."7 Thus, I clarify that hermeneutics is the philosophy of interpretation, which includes the meta-critique of interpretive methods and the

5 In this limited overview, I add that my experiences include living in five countries on four continents, teaching in five countries on three continents, mostly in Lutheran contexts. I currently live in Sweden and continue to engage in research in African biblical hermeneutics, teach African travel courses with Swedish students, and teach whenever possible in Africa.

6 Matthias Steup, "Epistemology," The Stanford Encyclopedia of Philosophy (Fall 2017 Edition), n.p. (ed. Edward N. Zalta), https://plato.stanford.edu/archives/fall2017/entries/epistemology.

7 Charles M. Wood, The Formation of Christian Understanding: An Essay in Theological Hermeneutics (Philadelphia: Westminster, 1981), 9. 
meanings created by the authors, texts and readers within their historicsituatedness or contexts.

The discussion continues with the exegesis of the text.

\section{GEN 16: ENTER HAGAR ${ }^{8}$}

Hagar appears in the context of the Abrahamic narrative. In Gen 11:27-32, Abram has moved from Ur of the Chaldeans (in contemporary Iraq) and has settled in Haran. However, YHWH has other plans for Abram, and somehow YHWH speaks to Abram (Gen 12:1), instructing him to go to a land that will be revealed, though it is not yet identified. With this imperative to go, YHWH makes promises to Abram:

I will make of you a great nation, and I will bless you and make your name great, so that you will be a blessing. I will bless those who bless you, and him who dishonors you I will curse, and in you all the families of the earth shall be blessed (Gen 12:2-3, ESV). ${ }^{9}$

At 75 years of age, Abram and his family faithfully depart, setting out for unknown regions. In various iterations through the next 16 chapters, the promises of the Abrahamic Covenant are repeated. ${ }^{10}$ Promises are summarised in four themes of the covenant: 1) of great nation/descendants, 2) land, 3) blessings and cursing doled out to others in parallel to their actions toward Abram and 4) blessings through Abram to all the world's people groups. ${ }^{11}$ These promises establish the red thread of the narrative, but the lack of timely fulfilmentespecially of an heir-enhances the tensions and raises questions regarding the sustainability of Abram's faith and whether YHWH would indeed bring these promises to fruition.

En route, a famine in Canaan turns the sojourners to Egypt. It is presumed that this is the time when Hagar, an Egyptian, enters into Abram's household as

8 The double entendre is intended.

9 All biblical quotations are taken from the ESV unless otherwise noted.

10 The promises of the Abrahamic covenant are repeated (Gen 15:1-21; 17:1-22; $22: 16-18 ; 26: 2-5,23-24)$ in different contexts and continue with reiterations to the next two generations of Isaac (Gen 28:13-15) and Jacob (Gen 28:13-15).

11 Gordon J. Wenham, Genesis 1-15 (ed. John D. W. Watts; Grand Rapids: Zondervan Academic, 1987), 277. Wenham identifies the interpretive issue of the translation of

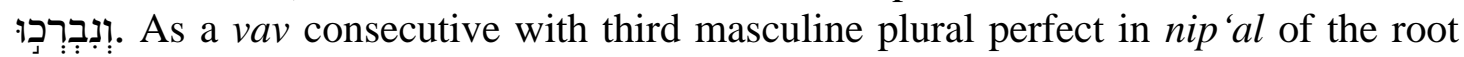
ברך , the standard English translations (ESV, NRSV, NIV, NLT) render the meaning as in passive voice. Possible alternatives are reflexive, "bless themselves" as seen in JPS, or middle voice in Wenham's own translation, "... and all the families of the earth will find blessing in you." 
Sarai's maidservant. ${ }^{12}$ As an Egyptian, ${ }^{13}$ Hagar is identified as African by David Adamo and Erivwierho Eghwubare. ${ }^{14}$ After the events in Egypt, Pharaoh sends Abram's household away (Gen 12:20) and they return to the Negeb region of Canaan.

Jumping over two chapters dealing with Abram's nephew, Lot, the narrative returns to the YHWH promises that are still pending fulfilment. In a vision, the words of YHWH came to Abram (Gen 15:1). Abram responds to these words of promise with doubt, pointing out that he currently has no heir and that Eliezer of Damascus will inherit Abram's estate, saying, "Behold, you have given me no offspring" (Gen 15:3). YHWH promises that Abram, indeed, will have his very own son as an heir and that his offspring will be as uncountable in number as the stars of the heaven. The revelation results in Abram believing and YHWH "counted it to him as righteousness" (Gen 15:6).

Ten years later (Gen 16:3), now Abram is 85 and Sarai is 75, and they are still without a child. Thus, Hagar enters the narrative when Sarai, the principal actor in the first part of this account, takes the initiative. With an imperative verb

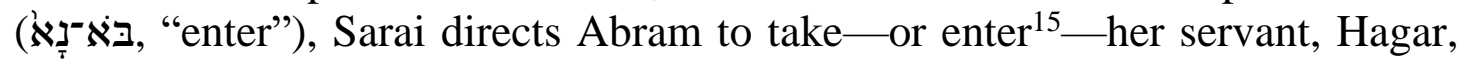
and provide a child so "it may be that I shall obtain children by her" (Gen 16:2). Katherine Doob Sakenfeld identifies that polycoity or taking an additional wife was probably not an unusual option for dealing with barrenness in such ancient contexts. ${ }^{16}$ In fact, Rachel gives her female servant, Bilhah, to Jacob, "so that she [Bilhah] may give birth on my [Rachel's] behalf" appears in Gen 30:3, followed

12 Gordon J. Wenham, Genesis 16-50 (ed. John D.W. Watts; Grand Rapids: Zondervan Academic, 2015), 6.

13 Madipoane (Ngwan'a Mphahlele) Masenya, "Professor David Tuesday Adamo's Biblical Scholarship on Women: Reflections from an African-South African Mosadi," OTE 33/2 (2020): 355. Masenya notes that all the other Egyptian women in the HB are "women of class" with Hagar as the exception.

14 David Tuesday Adamo and Erivwierho Francis Eghwubare, "The African Wife of Abraham (Gn 16:1-16; 21:8-21)," OTE 18/3 (2005): 457-461; Masenya, "Professor David Tuesday Adamo's," 352. While broad in scope and identifying several textual and interpretive issues, Adamo and Eghwubare's discussion of some perspectives that have sought to differentiate between Egypt and Africa or reframe the "physiognomical" characteristics of Egyptians as white is notable here. "Hence, Hagar can safely be described as an African, and in fact, a black African woman." Adamo and Eghwubare, "The African Wife of Abraham,"45, 9, 461.

15 The meaning is that "of entering a woman's tent or apartment (with implication coire cum femina..." Francis Brown, S.R. Driver and Charles A. Briggs, The BrownDriver-Briggs Hebrew and English Lexicon: With an Appendix Containing the Biblical Aramaic: Coded with the Numbering System from Strong's Exhaustive Concordance of the Bible (Reprint edition; Peabody: Hendrickson, 1996), 98.

16 Katharine Doob Sakenfeld, Just Wives: Stories of Power and Survival in the Old Testament and Today (Louisville: Westminster John Knox, 2003), 12. 
by Leah giving her servant, Zilpah, to Jacob in Gen 30:9. However, this text does not represent Hagar's perspective, whether she was amenable to this idea or not. It is possible to read this narrative as the sexual exploitation of a vulnerable woman. ${ }^{17}$ Phyllis Trible notes that Hagar is, "one of the first females in scripture to experience use, abuse, and rejection..." and that "Sarai exercises power over Hagar, the object." 18 Clearly, Sarai is the initiator who "gave" Hagar to Abram (v. 3) and any sense of Hagar's autonomy is not represented in the narrative. ${ }^{19}$ Nonetheless, the language indicates that there is an elevation of the status of Hagar from maidservant of Sarai to wife of Abram (לִאיטוֹה), ${ }^{20}$ which would afford greater security in a patricentric ${ }^{21}$ society. However, what could have enabled greater security does not undermine a clear stand against any unethical control over another human being, especially with regard to self-determination and autonomy over one's own body, seen in any sexual encounter, forced marriage or similar encounters. ${ }^{22}$ Nonetheless, as the narrative unfolds in a sad irony, her position as second wife actually endangers her security.

Hagar, voiceless and - at best - passive, conceives and thus, the conflict is born between the two women who are now co-wives. The ESV renders the

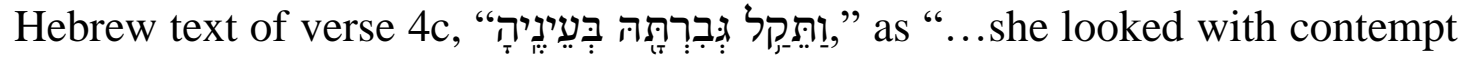
on her mistress," which changes the syntax such that Hagar is now the subject. Both the JPS and Trible retain the Hebrew syntax with "...her mistress was lowered in her esteem," and "her mistress was slight in her eyes," respectively. The concept of "contempt" or "lowered in esteem," from the root קָָל , occurs in

17 Michele Stopera Freyhauf, "Hagar: A Portrait of a Victim of Domestic Violence and Rape," n.p., https://feminismandreligion.com/2012/01/26/hagar-a-portrait-of-avictim-of-domestic-violence-and-rape.

18 Phyllis Trible, Texts of Terror: Literary-Feminist Readings of Biblical Narratives (Philadelphia: Fortress, 1984), 9, 11.

19 This is in contrast to the expressed consent that Rebekah gives in Gen 24:58.

20 Adamo and Eghwubare, "The African Wife of Abraham," 464. Adamo and Eghwubare note that "Elsewhere in the Old Testament, אִָָשה is translated as 'concubine' (Jdg 19:1, 27) and 'harlot' (e.g. Jos 2:1; 6:22; Jdg11:1)." However, they argue that in addition to the majority of translations that render אִשָׁה as "wife," the other word for

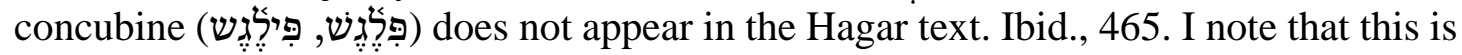
also a clear contrast to the use of concubine in the next chapter (Gen 22:24) and the following Jacob narrative (Gen 35:22). This language of wife is reframed as "slave woman" in the ESV in Gen 21:10, from אָָָָ, which BDB translates and "lit. maidservant" Ibid., 51.

21 Carol L. Meyers, "Was Ancient Israel a Patriarchal Society?," JBL 133/1 (2014): 9, https://doi.org/10.1353/jbl.2014.0012.

22 Furthermore, this ancient contextual understanding does not condone interpretations in contemporary contexts that oppress women by any means. 
all Semitic languages with the basic meanings of "be small, light." 23 This can be used as a cognitive pair that contrasts with "weighty" and "honoured," in the sense that Sarai's position is lessened in Hagar's eyes. ${ }^{24}$ However, this description does not come from Hagar who remains silent throughout the scene. Trible notes that this account is written "from the oppressor's perspective." 25 In fact, the same words "she conceived," "grew small," and "in her eyes" are repeated in the same order in the following verse (v.5) from Sarai's lips. The lack of details in this description-especially of emotional explanation-leaves interpretations pursuing the pitfall of speculation of Sarai's resentment. However, the text is clear that the description is Sarai's perception of Hagar. Hagar is not given any words to provide her testimony-her side of the storya case of testimonial injustice (defined below).

Sarai again is the assertive actor, now apportioning the blame on Abram for the perceived wrong done to her. Abram affirms that Hagar is in Sarai's

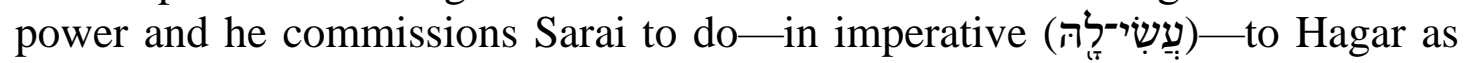
Sarai pleased (v. 6). Sarai's harsh dealings results in the pregnant Hagar fleeing. Hagar's flight is memorialised in her name. Hagar, an Egyptian, bears a probable Semitic name, ${ }^{26}$ from the root הגר, which appears in other Semitic languages. ${ }^{27}$ Nahum Sarna states that the name may mean "fugitive" 28 with a meaning connected to Arabic that includes "to flee." 29 Sarna continues that the name Hagar also "suggests a wordplay on Hebrew ger, 'stranger."” This root word and meaning is also reflected in the hajj, which in Islamic tradition remembers Hagar's desperate search for water during seven trips between two hills before discovering the providential spring, Zamzam. ${ }^{30}$ Thus, Hagar is remembered not by her own Egyptian name but rather by a foreign Semitic name meaning

23 Josef Scharbert, "קלל Q11," TDOT 13: 37; Wenham, Genesis 1-15, 1:276. The root קלל is the word used in the Abrahamic promise in Gen 12:3; for those who distain Abram God will distain. Wenham notes that it is milder than curse, ארר.

24 Scharbert, "קלל Q11," 38.

25 Trible, Texts of Terror, 9. Trible however clarifies that Sarai is also a victim of patriarchy. Ibid., 31.

26 Solomon O. Ademiluka, "Sexual Exploitation or Legitimate Surrogacy: Reading the Hagar Narrative (Gn 16:1-4a) in African Context," ThViat 43/1 (2019): 4, https://doi.org/10.4102/tv.v43i1.2.

27 Wenham, Genesis 16-50, 6.

28 Ibid., 6.

29 Nahum M. Sarna, The JPS Torah Commentary: Genesis (Philadelphia: Jewish Publication Society, 2001), 119.

30 Adamo and Eghwubare, "The African Wife of Abraham," 456; Chris Hewer, Understanding Islam: The First Ten Steps (London: SCM Press, 2006), 19-20; Fareeha Kahn, "Why Mecca? Abraham and the Hajj in the Islamic Tradition," in The Hajj: Pilgrimage in Islam (ed. Eric Tagliacozzo and Shawkat M. Toorawa; New York: Cambridge University Press, 2015), 31-64. 
"Fleeing One." However, this Semitic name is never used in the narrative by either Abram or Sarai. Hagar is only called by a name ${ }^{31}$ by the divine messenger of God (Gen 16:8; 21:17). ${ }^{32}$

The incongruous irony is that many aspects of the narrative contraindicate the established blessings of the Abrahamic Covenant. Blessing those who bless Abram should result in good for Hagar, who blessed Abram with a child. In addition, the promised descendants are jeopardised by sending Abram's first conceived child away, prior to the designation that Sarai shall bear the covenantal heir, identified in the next chapter (Gen 17:16). Furthermore, the blessing to all the people groups is not reflected in the mistreatment of a representative Egyptian. According to Iain Provan, one critical criterion for evaluating the praxis of the covenantal principle-blessing to all the people groups of the world - is whether other people groups are blessed through the Abrahamic family (Gen 12:3). ${ }^{33}$

A theophany shifts the scene to the spring on the way to Shur (v. 7) with a rare biblical occurrence of a woman receiving a divine encounter ${ }^{34}$ and in fact, this is the first identified visit by the divine messenger in the Bible. ${ }^{35}$ Furthermore, Hagar is the only non-Israelite, non-male to receive a blessing and a visit from the divine. ${ }^{36}$ At the beginning of this meeting, the messenger of YHWH 1) sees her, 2) addresses her by name, 3) asks her questions and 4) listens to her voice. For the first time in the narrative, Hagar speaks and tells her story.

\section{EPISTEMOLOGICAL INJUSTICE}

The Hagar narrative is an example of "epistemic injustice," as defined by the British philosopher, Miranda Fricker. ${ }^{37}$ She describes epistemic injustice as,

31 Note that in Gen 16:8, the address by name also includes the description, "servant of Sarai." Again, the narrator represents the account through the perspective of Sarai, as seen in the description of Hagar in 16:4 with Sarai's words in 16:5. While "wife of Abram" would have be a stronger position in the cultural context reflected in this literary setting, the account does not present Hagar defining herself in her own terms.

32 Adamo and Eghwubare, "The African Wife of Abraham," 467.

33 Iain Provan, The Writings, I: God's People in "Exile" in Old Testament Foundations (Vancouver, Canada, n.p., https://www.regentaudio.com/products/old-testament-foundations1 ? $\_$pos $=1 \&$ \& sid $=802467 \mathrm{a} 09 \& \&$ ss $=$ r.

34 Adamo and Eghwubare, "The African Wife of Abraham," 462.

35 Trible, Texts of Terror, 28.

36 Adamo and Eghwubare, "The African Wife of Abraham," 463; Masenya, "Professor David Tuesday Adamo's," 358.

37 Fricker, Epistemic Injustice, 1-8; "Miranda Fricker," City University of New York: Faculty Bios Philosophy, n.p., https://www.gc.cuny.edu/Page-Elements/Academics$\underline{\text { Research-Centers-Initiatives/Doctoral-Programs/Philosophy/Faculty-Bios/Miranda- }}$ 
"Being prevented from making your contribution to the pool of resources for which we use to create knowledge and shared understanding..." "38

One form of epistemic injustice is "testimonial injustice" or wrong done to someone specifically in their capacity as a knower. Fricker explains that, "Testimonial injustice occurs when prejudice causes a hearer to give a deflated level of credibility to a speaker's word." 39 This discrimination undermines the conveyance of knowledge - including one's own testimony - to others, as seen in Gen 16:4-5 where Hagar's testimony is excluded.

Fricker gives an example of testimonial injustice from an investigation into the British police's treatment of a black man at the scene of a murder. The black man — Dwayne Brooks, a friend of the murdered man-was presumed to be part of the problem instead of being one of the victims, demonstrating the mishandling of circumstances due to prejudicial assumptions. ${ }^{40}$ The police did not ask Brooks any questions at the crime scene, which Fricker identifies as a testimonial injustice. ${ }^{41}$

Similarly, the account of Hagar begins with her being silenced. Fricker states that "imposed silence" is "normally effected by way of an injustice" 42 and can be described also as a "pre-emptive testimonial injustice." 43 The narrator of this text has no references to Hagar's words or her own standpoint until her experience is validated through a divine encounter. Then, Hagar's own words are recorded and her contribution made to the pool of knowledge. Her statement includes an experience with and testimony to the nature of YHWH. The mistreatment of another human that results in her fleeing from abuse is a stark injustice. This atrocity is identified as a "text of terror" 44 with Hagar as one more

Fricker. Fricker earned a DPhil at the University of Oxford. She previously taught at Birkbeck College, London and at the University of Sheffield. Fricker currently holds the Presidential Professor of Philosophy position at City University of New York.

38 Fricker, "Epistemic Equality?"

39 Fricker, Epistemic Injustice, 1. The other form is hermeneutical injustice, which "occurs at a prior stage, when a gap in collective interpretive resources puts someone at an unfair disadvantage when it comes to making sense of their social experiences." An example of this is the inability to make sense of one's experience of "sexual harassment in a culture that lacks that critical concept." Ibid., 1.

40 William MacPherson, "The Stephen Lawrence Inquiry," National Archives, February 1999, n.p., http://www.archive.officialdocuments.co.uk/document/cm42/4262/4262.htm.

$41 \quad$ Fricker, “Epistemic Equality?,” sec. 12:05-17:15.

42 Miranda Fricker, "Silence and Institutional Prejudice," in Out from the Shadows: Analytical Feminist Contributions to Traditional Philosophy (ed. Sharon L. Crasnow and Anita M. Superson; New York: Oxford University Press, 2012), 287.

43 Fricker, "Epistemic Equality?," pt. 17:30.

44 Trible, Texts of Terror, 8-35. 
representative of the oppressed. ${ }^{45}$ While not dismissing the greater atrocities, this examination continues with a narrowed focus on the testimonial ostracism, which also is an injustice.

\section{E THE GOD WHO LISTENS AND SEES}

The theophany is a response from YHWH who listened to Hagar's affliction (v. 11). Sakenfeld identifies the conundrum in the text, "We learn of a God who does not always liberate the oppressed as they would like but who hears and responds to the cry of the desperate." 46 The messenger of YHWH instructs Hagar

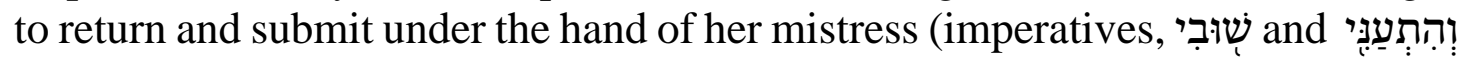

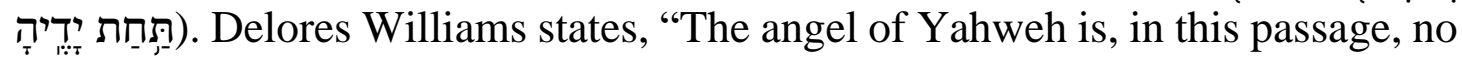
liberator God." However, while not providing liberation, the response does afford survival for a pregnant woman. ${ }^{47}$ In consolation, this disillusioning and difficult path is sustained by promises of: 1) the birth of a son, and 2) offspring multiplied such that they cannot be numbered. In Gen 21:18, the latter part is reiterated in a second theophany including a description of making the son into a great nation, which is interpreted by Adamo and Eghwubare as a promise of land. ${ }^{48}$ The divine messenger gives the expected son the name of Ishmael

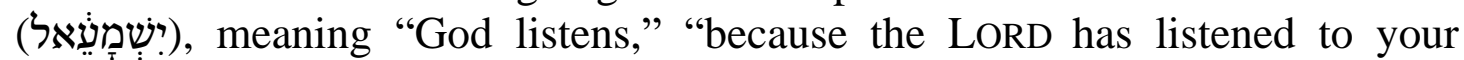
affliction" (v. 11). Indeed, Abram names the son Ishmael upon his birth, when Abram is 86 years old.

Nonetheless, naming is not only about Ishmael. Hagar gives a name to

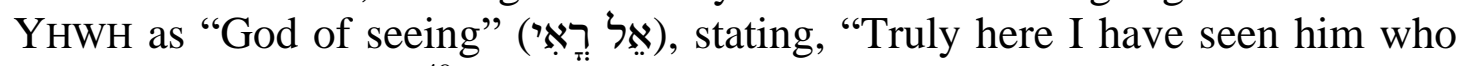
looks after me" (v. 13). ${ }^{49}$ Sarna identifies a "marvelous ambiguity" in the Hebrew that permits various translations that, likely, are "intended to be apprehended simultaneously" including "'God of seeing,' that is, the all-seeing God; 'God of my seeing,' that is, whom I have seen; 'God who sees me." 50 Adamo and Eghwubare point out that Hagar "becomes the only woman in the Bible given

45 Ibid., 28.

46 Sakenfeld, Just Wives, 7.

47 Ibid., 21. See Sakenfeld's discussion of the difficulty of this text and her conclusion that "our discomfort with that command requires us to work for liberation." Ibid., 22.

48 Adamo and Eghwubare, "The African Wife of Abraham," 462.

49 Wenham, Genesis 16-50, 3. Abridged notes on textual difficulty include: "Without emendation, the Hebrew is difficult, lit "Have I really seen hither after he has seen me?" BHS and many modern translations emend "hither" (הלם) to "God" (אלהים) and insert "and I lived," so that the whole remark reads "Have I really seen God and lived after my seeing (him)?" Westermann translates the phrase as, "Have I really seen God after he has seen me?" cf. T. Booij's proposal, "Would I have indeed looked hither for the one who sees me?" and Koenen's translation, "You are the God who sees me," for she said, "Truly I have seen him here who sees me." See also JPS, "Have I not gone on seeing after He saw me!"

50 Sarna, Genesis, 121. 
the chance to name God," 51 or as Trible describes, "the only person who dares to name the deity." ${ }^{25}$ Furthermore, Hagar's naming of God is memorialised in the

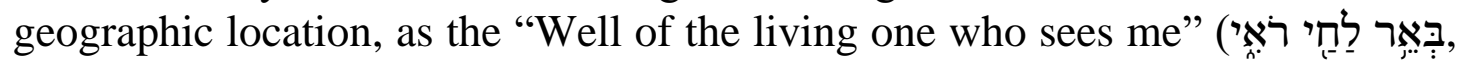
v. 14).

Hagar's narrative envisages: 1) a God who sees, 2) a God who asks to hear the testimony of the oppressed, 3) a God who listens and 4) a God who makes promises and sustains a vulnerable woman.

\section{F LISTENING TO MARGINALISED VOICES}

Thus, when one listens to an oppressed and marginalised woman's experience with God, the hearers can develop a fuller understanding of God. Hagar's words contributed to the pool of knowledge of the character of God seen within the Hebrew Scriptures, which continues to inform readers today.

Several scholars in feminist epistemology recognise that listening to marginal lives helps contribute to the understandings of social realities. ${ }^{53}$ Through listening to the oppressed, there is a fuller understanding of the conditions of society, which is needed to have an accurate diagnosis of the issues and together determine deliberate remedies. Oshadi Mangena argues that a holistic approach to knowledge requires a participatory democracy-that everybody must be invited to the process. ${ }^{54}$ Mangena continues that a participatory approach prevents fragmentations in understanding and holds in tension, "distinct but interrelated situational experiences" that better represent an integrated whole. ${ }^{55}$ Not only is disregarding marginalised voices an epistemic injustice, it diminishes the contributions to the pool of knowledge for all. ${ }^{56}$

51 Adamo and Eghwubare, "The African Wife of Abraham," 463.

52 Trible, Texts of Terror, 28.

53 Alessandra Tanesini, An Introduction to Feminist Epistemologies (Malden: WileyBlackwell, 1999), 151.

54 Oshadi Mangena, "Against Fragmentation: The Need for Holism," in Knowing the Difference: Feminist Perspectives in Epistemology (ed. Kathleen Lennon and Margaret Whitford; New York: Routledge, 1994), 279.

55 Mangena, "Against Fragmentation,” 278, 281.

56 This is not an argument that all voices are equally weighty in every dialogue, though all should have an opportunity to share their contribution for the common good. For example, there can be more sound voices in some disciplines or topics based on experience and/or training, for instance, in the case of health professionals or people sharing indigenous knowledge. The concern here is the marginalisation of voices by silencing or speaking for others without allowing the representation of their own experiences, a prejudicial dismissal of participants or at its worst, an abuse of power that actively oppresses other voices from being heard. See Fricker's discussion of power issues, Fricker, Epistemic Injustice, 9-17. 
Through the retelling of Hagar's story, the listeners and readers have a fuller depiction of the nature of YHWH.

As the African Hagar was marginalised then, the voices of African biblical scholars have been marginalised today. In the recent past, Justin Ukpong identified the testimonial injustice that African scholars faced as a result of methods, specifically contextual approaches practiced in African biblical hermeneutics that the Euro-American academies considered to be unscientific. ${ }^{57}$ Despite decades of critique from the philosophy of science, philosophical hermeneutics and feminist epistemology disciplines, the myth of unbiased scientific research persists. ${ }^{58}$ Donna Haraway, a feminist philosopher who also holds a PhD in biology, argues that science is a privileged voice and uses a narrative of objectivity to exert superiority over non-scientific voices. ${ }^{59}$ As these voices from the margins begin to be heard, their contributions enrich the pool of knowledge and enlarge the understanding of the character of God, as one looks "through the eyes of another." 60 In addition, these scholars expand the exegetical toolbox, as Andrew Mbuvi explains-Euro-American methods are too limiting to address the questions in African contexts. ${ }^{61}$ Engaging innovative approaches "inevitably provides a fresh analysis of the biblical text." ${ }^{62}$ Furthermore, looking through the references to Africa in the biblical texts through the eyes of

57 Justin S. Ukpong, "New Testament Hermeneutics in Africa: Challenges and Possibilities," Neot 35/1-2 (2001): 160.

58 Hans-Georg Gadamer, Truth and Method (New York: Continuum, 2004), 278-282; Donna Haraway, "Situated Knowledges: The Science Question in Feminism and the Privilege of Partial Perspective," Feminist Studies 14/3 (1988): 581, 595-596; Elisabeth Schüssler Fiorenza, "The Ethics of Biblical Interpretation: Decentering Biblical Scholarship," JBL 107/1 (1988): 5, 11-13.

59 Aileen Farrar, "Donna Haraway's Promises of Monsters," n.p., https://www.youtube.com/watch?v=wsMCVn7tvfc. Donna Haraway, "The Promises of Monsters: A Regenerative Politics for Inappropriate/d Others," in Cultural Studies (ed. Lawrence Grossberg, Cary Nelson and Paula A. Treichler; New York: Routledge, 1992), 313.

60 Hans de Wit et al., eds., Through the Eyes of Another: Intercultural Reading of the Bible (Elkhart: Institute of Mennonite Studies, 2005); Knut Holter, "Norwegian, Malagasy and Thai Youths Reading Luke 15 Together," in A Critical Study of Classical Religious Texts in Global Contexts: Challenges of a Changing World (ed. Beth E. Elness-Hanson and Jon Skarpeid; New York: Peter Lang, 2019), 139-152. These sources are two examples of the enriching understandings of God that develop through intercultural Bible reading and listening to other voices.

61 Andrew M. Mbuvi, "African Biblical Studies: An Introduction to an Emerging Discipline," Currents in Biblical Research (2017): 149.

62 Mbuvi, "African Biblical Studies," 150. 
contemporary African scholars provides another perspective. ${ }^{63}$ Exemplars of African perspectives include the seminal work of David Tuesday Adamo, who encourages readers to be open to listening to "radical new ideas different from the mainline Eurocentric conception of the black people" [in the Bible]. ${ }^{64}$

Thus, as listening to Hagar provides a fuller understanding of the nature of God, listening to African scholars like Adamo and other Majority World voices helps provide a fuller conceptualisation of God-and hearers are enriched by them.

\section{H BIBLIOGRAPHY}

Adamo, David. Africa and the Africans in the Old Testament. Reissue edition. Eugene: Wipf and Stock, 2001.

Adamo, David Tuesday and Erivwierho Francis Eghwubare. "The African Wife of Abraham (Gn 16:1-16; 21:8-21)." Old Testament Essays 18/3 (2005): 455-471.

Ademiluka, Solomon O. "Sexual Exploitation or Legitimate Surrogacy: Reading the Hagar Narrative (Gn 16:1-4a) in African Context." ThViat 43/1 (2019). Cited 5 April 2019. Online: https://doi.org/10.4102/tv.v43i1.2.

Botterweck, G. Johannes, Helmer Ringgren and Heinz-Josef Fabry, eds. Theological Dictionary of the Old Testament. Grand Rapids: Eerdmans, 2004.

Brown, Francis, S. R. Driver and Charles A. Briggs. The Brown-Driver-Briggs Hebrew and English Lexicon with an Appendix Containing the Biblical Aramaic: Coded with the Numbering System from Strong's Exhaustive Concordance of the Bible. Reprint edition. Peabody: Hendrickson, 1996.

Cambridge Dictionary. "Meaning of Respect in English." Cited 9 August 2021. Online: https://dictionary.cambridge.org/dictionary/english/respect.

City University of New York: Faculty Bios Philosophy. "Miranda Fricker." Cited 13

December 2020. Online: https://www.gc.cuny.edu/Page-Elements/Academics-

Research-Centers-Initiatives/Doctoral-Programs/Philosophy/Faculty-

Bios/Miranda-Fricker.

De Wit, Hans, Louis Jonker, Marleen Kool and Daniel S. Schipani, eds. Through the Eyes of Another: Intercultural Reading of the Bible. Elkhart: Institute of Mennonite Studies, 2005.

Durant, Elizabeth. "It's Complicated: Power and Complicity in the Stories of Hagar and Sarah." Conversations with the Biblical World 35 (2015): 78-93.

Farrar, Aileen. "Donna Haraway's Promises of Monsters." Cited 2 April 2015. Online: https://www.youtube.com/watch?v=wsMCVn7tvfc.

Freyhauf, Michele Stopera. "Hagar: A Portrait of a Victim of Domestic Violence and Rape." $\quad$ Cited $26 \quad$ January $2012 . \quad$ Online:

63 Elizabeth Durant, "It's Complicated: Power and Complicity in the Stories of Hagar and Sarah," Conversations with the Biblical World 35 (2015): 79.

64 David Adamo, Africa and the Africans in the Old Testament (Reissue edition; Eugene: Wipf \& Stock, 2001), 6. 
https://feminismandreligion.com/2012/01/26/hagar-a-portrait-of-a-victim-ofdomestic-violence-and-rape.

Fricker, Miranda. "Epistemic Equality?" Lecture Presented at the Social Equality Conference, UCT Philosophy, Cape Town, South Africa. Cited 10 September 2014. Online: https://www.youtube.com/watch?v=u8zoN6GghXk.

. Epistemic Injustice: Power and the Ethics of Knowing. Oxford: Oxford University Press, 2009.

"Silence and Institutional Prejudice." Pages 287-306 in Out from the Shadows: Analytical Feminist Contributions to Traditional Philosophy. Edited by Sharon

L. Crasnow and Anita M. Superson. New York: Oxford University Press, 2012.

Gadamer, Hans-Georg. Truth and Method. New York: Continuum, 2004.

Grimm, Joe. “Associated Press Changes Style on Race, Gender.” Bias Busters: Cultural

Competence Guides. Cited 5 April 2019. Online:

https://news.jrn.msu.edu/culturalcompetence/2019/04/05/associated-presschanges-styl-on-race.

Haraway, Donna. "Situated Knowledges: The Science Question in Feminism and the Privilege of Partial Perspective.” Feminist Studies 14/3 (1988): 575-599.

"The Promises of Monsters: A Regenerative Politics for Inappropriate/d Others." Pages 295-336 in Cultural Studies. Edited by Lawrence Grossberg, Cary Nelson and Paula A. Treichler. New York: Routledge, 1992.

Hewer, Chris. Understanding Islam: The First Ten Steps. London: SCM Press, 2006.

Holter, Knut. "Norwegian, Malagasy and Thai Youths Reading Luke 15 Together." Pages 139-152 in A Critical Study of Classical Religious Texts in Global Contexts: Challenges of a Changing World. Edited by Beth E. Elness-Hanson and Jon Skarpeid. New York: Peter Lang, 2019.

Kahn, Fareeha. "Why Mecca? Abraham and the Hajj in the Islamic Tradition." Pages 31-64 in The Hajj: Pilgrimage in Islam. Edited by Eric Tagliacozzo and Shawkat M. Toorawa. New York: Cambridge University Press, 2015.

MacPherson, William. "The Stephen Lawrence Inquiry." National Archives, February 1999. Cited 13 December 2020. Online: http://www.archive.officialdocuments.co.uk/document/cm42/4262/4262.htm.

Mangena, Oshadi. "Against Fragmentation: The Need for Holism." Pages 275-282 in Knowing the Difference: Feminist Perspectives in Epistemology. Edited by Kathleen Lennon and Margaret Whitford. New York: Routledge, 1994.

Masenya, Madipoane (Ngwan'a Mphahlele). "Professor David Tuesday Adamo's Biblical Scholarship on Women: Reflections from an African-South African Mosadi." Old Testament Essays 33/2 (2020): 348-362.

Mbuvi, Andrew M. "African Biblical Studies: An Introduction to an Emerging Discipline." Currents in Biblical Research (1 February 2017): 149-178.

Meyers, Carol L. "Was Ancient Israel a Patriarchal Society?" Journal for Biblical Literature 133/1 (2014): 8-27. Cited 13 December 2020. Online: https://doi.org/10.1353/jbl.2014.0012.

Provan, Iain. The Writings, I: God's People in "Exile." Old Testament Foundations. Vancouver, Canada, 2007. Cited 20 October 2019. Online: 
https://www.regentaudio.com/products/old-testament-foundations-

1 ? $\_$pos $=1 \&$ \& sid=802467a09\&_ss=r.

Sakenfeld, Katharine Doob. Just Wives: Stories of Power and Survival in the Old Testament and Today. Louisville: Westminster John Knox, 2003.

Sarna, Nahum M. The JPS Torah Commentary: Genesis. Philadelphia: Jewish Publication Society, 2001.

Scharbert, Josef. "קלל Q11," in Theological Dictionary of the Old Testament. Edited by G. Johannes Botterweck, Helmer Ringgren and Heinz-Josef Fabry, 13:37-44. Grand Rapids: Eerdmans, 2004.

Schüssler Fiorenza, Elisabeth. "The Ethics of Biblical Interpretation: Decentering Biblical Scholarship.” Journal of Biblical Literature 107/1 (1988): 3-17.

Steup, Matthias. "Epistemology," No Pages in The Stanford Encyclopedia of Philosophy (Fall 2017 Edition). Edited by Edward N. Zalta. 14 December 2017. Cited $20 \quad$ October 2020.2 Online: https://plato.stanford.edu/archives/fall2017/entries/epistemology.

Sullivan, Margaret. "Perspective Tucker Carlson's Mangling of Kamala Harris's Name Was All about Disrespect." Washington Post. Cited 13 August 2020. Online: https://www.washingtonpost.com/lifestyle/media/tucker-carlsons-mangling-ofkamala-harriss-name-was-all-about-disrespect/2020/08/12/ea573d06-dca7-11ea809e-b8be57ba616e_story.html.

Tanesini, Alessandra. An Introduction to Feminist Epistemologies. Malden: WileyBlackwell, 1999.

Trible, Phyllis. Texts of Terror: Literary-Feminist Readings of Biblical Narratives. Philadelphia: Fortress, 1984.

Ukpong, Justin S. "New Testament Hermeneutics in Africa: Challenges and Possibilities." Neotestamentica 35/1-2 (2001): 147-167.

Wenham, Gordon J. Genesis 1-15. World Biblical Commentary. Volume 1. Grand Rapids: Zondervan Academic, 1987.

. Genesis 16-50. World Biblical Commentary. Volume 2. Grand Rapids: Zondervan Academic, 2015.

Wood, Charles M. The Formation of Christian Understanding: An Essay in Theological Hermeneutics. Philadelphia: Westminster, 1981.

Beth E. Elness-Hanson is Lecturer in Old Testament at Johannelund School of Theology, Uppsala, Sweden, and part-time Associate Professor at VID Specialized University, Stavanger, Norway. Email address: beth.elnesshanson@johannelund.nu. ORCID ID https://orcid.org/0000-0001-9234-6241 